\title{
Role of Forensic Evidence in Upholding Justice: Exploring Islamic Law and the Experience of Syariah Courts in Malaysia
}

\author{
Abdul Basir Mohamad* and Nurbazla Ismail \\ Research Centre for Sharia, Faculty of Islamic Studies, Universiti Kebangsaan Malaysia (UKM), \\ 43600 Bangi, Malaysia
}

\begin{abstract}
In Islamic law of evidence, there are several forms of evidence commonly used by courts to establish facts. In today's era, a form of evidence called forensic evidence has also emerged. A question then arises, what is the appropriate legal basis for acceptance of this forensic evidence in the Islamic law of evidence. This paper focuses on the evolution of the Islamic law of evidence and investigates the position of forensic evidence in Islamic law from sources such as the Quran, the Prophet's traditions, and the practices of the Companions of the Prophet. In addition, this study also looks at the experience of the Malaysian Syariah Courts in terms of how forensic evidence is dealt with in hearing family law cases. The research design of this study is content analysis. Data were obtained by document analysis, including books, papers, journals, case reports, and other records relating to the role of forensic evidence. The methods used to interpret the data for this qualitative research are analytical and deductive. As a result, it can be said that forensic evidence is not an unfamiliar matter in the Islamic law of evidence. In fact, forensic evidence has been relied on by the Syariah Courts of Malaysia in making several decisions for certain cases in order to ensure that justice is upheld in society.
\end{abstract}

Keywords: Circumstantial evidence, forensic evidence, Islamic law of evidence, Islamic justice, Syariah Court

ARTICLE INFO
Article history:
Received: 23 October 2020
Accepted: 15 March 2021
Published: 30 June 2021
DOI: https://doi.org/10.47836/pjssh.29.2.19
E-mail addresses:
abasir@ukm.edu.my (Abdul Basir Mohamad)
nurbazla@ukm.edu.my (Nurbazla Ismail)
* Corresponding author
ISSN: 0128-7702
e-ISSN 2231-8534

\section{INTRODUCTION}

What is forensic? In general, it means the application of scientific methods and techniques to the investigation of crime. In other words, forensic can be understood as a body of knowledge relating to scientific methods of solving crimes, involving examination of objects or substances that are 
involved in the crime. According to Glugston (1998), forensic science is the application of scientific techniques in the investigation of a case. Thus, we can say that forensic science refers to a branch of science that is used in the investigation process to obtain proof (Pass \& Allan, 2009). For example, forensic medicine would be relevant in the case of a person's death caused by poison. Thus, the court needs someone who has the expertise in the medical field to determine the cause of death for judicial purposes in court proceedings. The knowledge relating to the determination of cause of death, for example the finding of any sign indicating that the victim has been poisoned is an example of forensic expertise.

There are many different types of forensic evidence in scientific practice. Among the major categories of forensic evidence are DNA, fingerprints, and bloodstain pattern analysis. Fingerprint evidence can be more important than DNA in cases where identical twins are involved. As currently practiced, the information given to the court either by scientists or by other technical skilled persons is regarded as an expert forensic witness. For example, any evidence submitted by the police to the court such as fingerprints, blood, and hair is referred to as forensic evidence.

In Islamic law of evidence, forensic evidence often referred to its relevance as qarinah and ra'y al-khabir. However, the focus of this study is the acceptance of $r a$ ' $y$ al-khabir and qarinah in terms of reliability, validity, and strength to be accepted as forensic evidence. The terms of forensic evidence used in this study are referred to the evidence obtained by scientific methods testified by the expert forensic witness who was called to the court to give the testimony to strengthen the facts in the cases. Analysis of forensic evidence is used in civil as well as criminal proceedings and can often help to establish the guilt or innocence of possible suspects. Forensic evidence can also be used to link between one crime and another. For example, DNA evidence can link the same offender to several different crimes. This linking of crimes helps the authorities to narrow the range of possible suspects and to identify patterns of crimes.

In Malaysia, there was no specific reference to forensic evidence in the Evidence Act 1950. As the study was concerned, forensic evidence relates to an expert forensic witness. The definition of experts should therefore be referred to in Section 45 of the EA 1950 that is a person especially skilled in foreign law, science, or art, or in questions as to identity or genuineness of handwriting or finger impressions. Similar to that set out in Section 33 of the Syariah Court Evidence Act (Federal Territories) 1997 on the definition of an expert. However, the Malaysian Syariah Courts use the definition of an expert as a qarinah. The word "science" in both of the definitions has shown that the discussion on forensic evidence should refer to this legal provision.

\section{METHODS}

This study is qualitative research as it focuses on the subject of the study; the role of forensic evidence in upholding 
justice. The research design of this study is content analysis. Data were collected using document analysis, namely books, articles, journals, case reports, and other materials relating to the role of forensic evidence. This research makes use of both primary data and secondary data such as articles and journals from electronic sources, books, and also the cases in court which is unpublished material. All of these materials are important because they help provide a detailed explanation of the topic. The approaches used to analyse the data under this qualitative research are analytical, deductive, and inductive. Analytical is the purpose to look at an issue more closely and in-depth for example: what is forensic? In this study, the deductive method was used to conclude the subtopic mostly by doing some predictions upon which is deduced from the acceptance of forensic evidence by the Quran.

\section{SIGNIFICANCE OF FORENSIC EVIDENCE IN THE ISLAMIC JUSTICE PROCESS}

In the judiciary process, the law of evidence is very important. With it, the judge can decide upon any claim or dispute between parties with a higher degree of proof. There are many Quranic verses that prohibit the people from concealing evidence, command them to give evidence honestly, and demand that they must be trustworthy and just. This is on the reason that by giving the evidence is meant as conveying information and confession as a trustee and a witness before Allah. The Quran says in Surah al-Nisa', verse 58 , which means:

\begin{abstract}
Allah doth command you to render back your trusts to those to whom they are due, and when ye judge between man and man, that ye judge with justice, verily how excellent is the teaching which He giveth you! (al-Qur'an, al-Nisa'4: 58)
\end{abstract}

This verse vividly commands the people to judge between themselves (the disputants) with justice and equity. If the dispute is related to a trust item, that item is something that must be preserved as best as possible and it must be returned to its owner upon expiration. The sense of justice here is obligatory and delivering justice is the responsibility of all. Therefore, if justice can be upheld through the process of forensic evidence, then a forensic investigation must be carried out in order to ensure justice is obtained in a particular case.

The Quran says in Surah al-Ma'idah, verse 42, which means:

If thou judge, judge in equity between them, for Allah loveth those who judge in equity. (alQur'an, al-Ma'idah 5: 42)

In verse 49 of Surah al-Ma'idah, the Quran says, which means:

And this (He commands): judge thou between them by what God hath revealed, and follow not their vain desires, but beware lest they beguile thee from any of that (teaching) which God hath sent down to thee. (al-Qur'an, alMa'idah 5: 49) 
In this verse, Allah commands the Prophet to judge disputes between people by that which Allah has revealed and ordered, and not to follow their desires, and to beware against some people who may tempt the Prophet away from what Allah has revealed to him. From this verse, it can be understood that if the process of analysis of equipment or of limbs of the victim involved can help to obtain evidence to solve a case, then the process of forensic investigation must be carried out.

The Quran says in Surah al-Nisa', verse 105 which means:

\section{We have sent down to thee the Book} in truth, that thou might judge between men, as guided by Allah, so be not (used) as an advocate by those who betray their trust. (alQur'an, al-Nisa'4: 105)

People would be able to value justice when it can be implemented with efficiency, trust, and equity. The judge, therefore, should be qualified to preside over the judicial proceedings as has been commanded by Allah. In every case, Allah commands men to act justly, and not to let enmity lead them to deviate from justice. The Quran says in Surah al-Ma'idah, verse 8 which means:

O ye who believe! Stand out firmly for Allah, as witnesses to fair dealing, and let not the hatred of others to you make you swerve to wrong and depart from justice. Be just, that is next to piety. (alQur'an, al-Ma'idah 5: 8)
It is not enough for people to uphold justice they are expected to be its standardbearers. They are not supposed to be concerned with justice merely in their own dealings but should always strive for its triumph. They should do everything within their power to ensure that injustice is eradicated and replaced with equity and fairness (al-Mawdudi, 1978).

The testimony of the people should be offered solely for the sake of Allah. Their testimony should not be biased in favour of any party. They should not make use of any opportunity for personal aggrandizement, and they should not seek to please anyone other than Allah.

Since justice is one of Allah's attributes, Qadri (1973) stressed that one has to stand firm for it. Godly justice is higher than manmade justice, for it searches out the innermost motives because men are to always act as if they are in the presence of Allah, to whom all things, acts, and motives are known.

The Quran says in Surah al-Nisa', verse 135 which means:

O ye who believe! Stand out firmly for justice, as witnesses to God, even as against yourselves, or your parents, or your kin, and whether it be (against) rich or poor, for God can best protect both. Follow not the lusts (of your hearts), lest ye swerve, and if ye distort (justice) or decline to do justice. (al-Qur'an, al-Nisa' 4: 135)

This verse declares that all information and testimony, including any forensic 
evidence, should be given without any discrimination, even though it may be unfavourable to our own interests or to the interests of our parents or kinsmen. The witnesses who are called to court are the witnesses of Allah, therefore their being present as a witness to give testimony in court is due to Allah, not to anything else. The triumph in a trial is meant to be taken as the triumph of justice and the triumph of the security of rights. The Quran says in Surah al-Baqarah, verse 283 which means:

Conceal not evidence, for whoever conceals it, his heart is tainted with sin. (al-Qur'an, al-Baqarah 2: 283)

Concealing true evidence applies both in cases where a person does not appear to give evidence and where he avoids stating facts (al-Mawdudi, 1978). Whoever has any facts or evidence in a case, Islamic law commands that person to give co-operation as a witness. Likewise, the experts, are also urged to use their expertise and skills to help the court to identify the actual offenders. Without them, it would be difficult for the court to uphold justice in society.

The Quran says in Surah al-Baqarah, verse 282 which means:

The witnesses should not refuse when they are called on (for evidence). (al-Qur'an, al-Baqarah 2: 282)

The above verse means that no person should refuse when they are summoned (to give evidence). Such obligation has been placed upon every person in order to be able to achieve justice in society. Likewise, when experts or skilled persons are called upon to the court to submit their views in certain cases, it becomes their responsibility to do so in order to achieve justice in society.

\section{ACCEPTANCE OF FORENSIC EVIDENCE BY THE QURAN, THE PROPHET'S TRADITION, AND THE PRACTICES OF HIS COMPANIONS}

Among the types of evidence accepted by Islamic law is the opinion of experts, also known as expert evidence. In Islamic law terminology, the testimony given by a particular expert on a case is referred to as raý al-khabir. According to Bahnasi (1962), expert testimony is the opinion given by someone who has expertise in a relevant field related to a particular case. For example, in cases involving death suspected to have been caused by certain factors, the judge needs to have a certain level regarding what exactly caused the victim to die. Therefore, the court needs to obtain accurate and authentic evidence through the views and opinions of experts in the field of forensic medicine.

Expert opinion is usually concerned with scientific and technical elements involving people who are highly skilled in a particular field, such as scientists, technicians, and forensic medicine expertise. In such cases, the court will have to rely on the testimonies given by experts to assist the court in making a decision.

In the Islamic law of evidence generally, the means of proof are confession, testimony, and oath. Is forensic evidence acceptable in 
Islamic law? The Quran says in Surah alNahl, verse 43, it means:

\section{And We sent not before you except men to whom We revealed [Our message]. So ask the people of the message if you do not know. (al- Qur'an, al-Nahl 16: 43)}

In this verse, Allah commands believers to ask the people who have received the message if they do not have knowledge as to a specific thing. According to a few commentators of the Quran like alQurtubi (1950), people of the message are the persons who have knowledge in a particular field or in a certain matter. Thus, we can say that judges, lawyers, and also prosecutors generally do not possess knowledge in specific fields such as pure science, mechanical engineering, medical pharmacology, medical diseases, and others. Hence, according to the above Quranic verse, when a case comes to the court which requires some scientific evidence, it becomes the court's obligation to pursue persons having that knowledge or expertise on the relevant specific matter, such as medical doctors, chemists, pathologists, and others who have sufficient knowledge to guide the court in the right direction in deciding such a case.

Ibn Qayyim (n.d.) gave some examples related to the need for forensic experts to testify in court. For example, the task of identifying the types of wounds, and determining whether they are serious wounds or not, should be done by a doctor who specializes in the relevant type of injury. Similarly, if the court needs proof in relation to veterinary medicine, of course, it would be necessary to consult the views of a veterinarian.

In another Quranic verse, namely Surah Yusuf, verse 18, we are told the story of the Prophet Yusuf, where his brothers claimed that the Prophet Yusuf was killed by a wolf, which means:

And they brought upon his shirt false blood. [Jacob] said, "Rather, your souls have enticed you to something, so patience is most fitting. And Allah is the one sought for help against that which you describe. (al-Qur'an, Yusuf 12: 18)

According to the interpretations of alQurtubi (1950), the jurists have said that Prophet Ya'qub, the father of Prophet Yusuf, knew of the lies committed by the brothers of Prophet Yusuf by only seeing the clothes of Prophet Yusuf that had been handed over to him which were still in good and perfect condition so that Prophet Ya'qub said: When will the wolf become wise, he ate Yusuf but did not tear his clothes?

From the story of the Prophet Ya'qub and the Prophet Yusuf above, we can say that the Prophet Ya'qub was a man of high knowledge, and therefore he could figure out that what was told to him about the Prophet Yusuf having been killed by a wolf was a lie. The evidence he received was a fraud. The Prophet Ya'qub was able to know all that through the high knowledge and skill he possessed. The height of knowledge that the Prophet Ya 'qub had can be compared to the expertise in forensic science today. 
Another example that supports the argument that forensic evidence is acceptable by Islamic law is the Quranic verses 25-28 of Surah Yusuf, which means:

And they both raced to the door, and
she tore his shirt from the back, and
they found her husband at the door.
She said, "What is the recompense
of one who intended evil for your
wife but that he be imprisoned or a
painful punishment?" [Yusuf] said,
"It was she who sought to seduce
me." And a witness from her family
testified. "If his shirt is torn from the
front, then she has told the truth,
and he is of the liars. But if his shirt
is torn from the back, then she has
lied, and he is of the truthful." So
when her husband saw his shirt torn
from the back, he said, "Indeed, it
is of the women's plan. Indeed, your
plan is great. (al-Qur'an, Yusuf 12 .
25-28)

These verses tell about the Prophet Yusuf's struggle to escape from a woman who wanted to embrace and hug him. As a result, his shirt was torn from the back and the woman's husband had been able to discover that his wife had lied and that the Prophet Yusuf was a righteous man.

In the above verses, the words "witness from her family" refers to a man or a wise man, who had witnessed the case and can be said to be a skilled person, which in our time can be likened to a forensic expert. In this incident, the person in question was one with great insights with regard to the situation.
There are also some cases taken from the Prophet's traditions that can be linked to forensic practice. One example is that the Prophet once made a decision based on the views and opinions of experts who determined the lineage of a companion. The Prophet accepted the views of hereditary experts as proof of lineage.

The science of determining lineage is called qiyafah and it was pioneered in the time of the Prophet by some of the Arabs including Bani Mudlij which was mentioned in several stories in the time of the Prophet, among them the story of Usamah and his son Zayd. Qiyafah in terms of language means the physical matching of one object with another object. Meanwhile from a practical point of view, matching one's lineage with that of another person can be done through the physical features or characteristics of one's appearance.

A person who specializes in the field of qiyafah is called qa'if, namely one who is an expert in determining the lineage or offspring of someone. In brief, we can say that qa' if is a person who has the skills, ability, expertise, knowledge, and the trust of the community to practice qiyafah. It is recorded in the classical record that those known as qa 'if are not specific to a particular tribe or race (Zaydan, 1984). In fact, a qa 'if can be anyone having special knowledge and the ability to put that knowledge into practice. Shabana (2012) mentioned that the role played by qa'if can be likened to the role of forensic experts and scientists today. From the record, a companion named Mujazziz al-Mudlaji from Bani Mudlij, 
Umar al-Khattab and his father al-Khattab bin Nufayl, Abu Ubaydah al-Jarrah, and also the Bani Asad were among those having skill, talent, and expertise in this field (Hoyland, 2005; Shabana, 2012).

It has been related by the authority of A'ishah that one day the Prophet came to her with extreme happiness, 'O A'ishah, do you not see that Mujazziz al-Mudlaji looked at Usamah bin Zayd and Zayd bin Harithah and both of them were under a blanket, both of them had their heads covered and their legs were exposed and he (Mujazziz) said:

Indeed, some of these legs come from one another (similar). (Muslim, (1412H/1991M).

The happiness of the Prophet upon hearing Mujazziz's opinion on the lineage of Usamah bin Zayd shows that the Prophet had recognized Mujazziz's expertise in the field of determining lineage.

From this tradition of the Prophet, the indication is that Islamic law accepts the views of experts when a case has to be decided.

Another case that can also be used to relate to forensic science is the case of the assassination of Abu Jahl in the battle of Badr by two young men of 'Ufra, who both claimed that they had killed Abu Jahl. The Prophet asked them whether they had washed their swords. They answered 'no'. When the Prophet looked at their swords, he found that blood still stained one of the swords. He decided that the owner of the sword which still had blood on it was the rightful party in his claim.
Similarly, it has been narrated that Umar bin al-Khattab had made a decision without any objection from other companions regarding the fixed (hudud) punishment for adultery upon an unmarried pregnant woman based on clear evidence (Malik, 1989). In another case, Abdullah bin Mas 'ud decided to whip an alcoholic person based on the smell of alcohol on his mouth (Zaydan, 1984).

\section{RESULTS AND DISCUSSIONS}

Forensic Evidence in the Court: To What Extent it is Acceptable as a Form of Evidence

In this matter, the Islamic schools of law have differing approaches. Some of them accept the forensic evidence to serve as proof in all cases, including for cases of fixed punishment, as long as the evidence is strong and undoubted. However, others do not accept forensic evidence except for civil cases. Accordingly, for criminal cases such as adultery, drinking alcohol, qazaf, and murder cases, the only types of evidence admissible are confession and witness testimonies. This means that the level of strength is different in criminal and civil cases, depending on the discretion of the judge who assesses the strength of the evidence against a great deal of prejudice in the proceedings.

Forensic evidence may be accepted as evidence for the use of ra'y al-khabir and qarinah. In criminal cases, the qarinah must be proved beyond reasonable doubt and the level of strength for civil cases is the balance of probabilities. Forensic evidence 
such as qarinah or ra'y al-khabir cannot be used directly but is used to support other evidence. For example, in the case of takzir, both qarinah and ra'y al-khabir can be used to reinforce the evidence to prove the case.

Among the Islamic schools of law that accept forensic evidence for all cases are the Maliki and Hanbali schools of law. As stated by Ibn Farhun (1884): 'Indeed a part of methods of judgment in the Maliki school is to adhere to circumstantial evidence'. From this statement, it can be understood that the Maliki school of law accepts forensic evidence as one of the methods of providing proof for all cases, given that forensic evidence was recognised as one of the categories of circumstantial evidence or qarinah.

Likewise, in the Hanbali school of law, Ibn Qayyim (n.d.) stated: 'The opinion of one doctor is sufficient in cases of serious injury if two are not available. Similarly, the expert witness of one veterinarian is sufficient in cases of the disease of an animal'. The Hanbali School of Law accepts forensic evidence as a testimonial to the expert witness. The doctor is an expert to justify the injury to humans and the veterinarian is an expert to determine the injury to humans.

The Islamic justice system is not narrow and troublesome, in fact, it strongly emphasizes that justice must be upheld in any circumstances. Therefore, if a judge finds it difficult to decide a case and requires the views of experts such as doctors, scientists, veterinarians, pharmacists, and others, the judge must obtain their expert views first before making a decision. In this regard, al-Sarakhsi (1986) stated: "If a ruler faces difficulty in determining the value of the stolen property he should seek the opinions of the experts. But if the experts differ in their opinions about the values, for example, some of them estimate it at ten dirhams and the others fix it by less than that, the punishment of hudud will not be implemented on the person accused because such a fixed punishment would be implemented when the amount of the stolen property reaches a specified amount and it is reckoned not enough when there is a difference of opinion among the experts as to its value".

In his record, Ibn Qayyim (n.d.) explained the position of Islamic scholars regarding the use of forensic evidence. He said that although they did not explicitly adhere to the use of expert evidence to establish proof in court, in reality for certain cases they refer to the views of experts to make decisions. For example, in the case of treasure (rikaz), should there be signs that it was owned by Muslims, then it is considered as property found (luqatah) but if there are signs that it was owned by non-Muslims, then it is counted as treasure. To see whether that property was owned by Muslim or not Muslim, surely an antique expert would need to be called in to make a determination of the matter.

The relevance of expert opinions in resolving a court case has also been expressed by contemporary Muslim scholars. Among them is al-Zuhayli (1998) who stated that a female doctor's opinion is required to 
determine whether or not the virginity of a woman is intact. Likewise, in cases to decide the amount of compensation payable for injuries, the opinion of a specialist doctor is required. Meanwhile, in order to check the existence of latent defects on consumer goods, the opinion of an expert on goods is required. In both cases, the opinion of the doctor as an expert witness can be used to reinforce the facts of the case in court.

Thus, this study has shown that qarinah and ra'y al-khabir are relevant and acceptable as forensic evidence in court based on the discussion of the Islamic Law School.

\section{Forensic Evidence in Malaysia: The Experience of the Syariah Court}

Forensic evidence has long been admissible in the Syariah Courts of Malaysia for purposes of establishing facts. As is well known, the use of forensic evidence in the Syariah Courts is not limited to civil cases only. However, a Syariah Court does not have the jurisdiction to handle serious criminal cases such as murder, theft, rape, and so on. Among the types of cases heard in the Syariah Court which allow forensic evidence to be admitted are cases relating to the determination of lineage and confirmation of the pronouncement of divorce.

\section{Cases on Determination of Lineage.}

Forensic evidence was relied on in the following cases to determine the doubtful lineage of a child.

\section{The Case of Sabah State Syarie Prosecutor} v. Rosli Abdul Japar [2007] 1 CLJ SYA 496. The accused in this case, Rosli bin Japar, was charged with an offence under s. 80(1) of the Syariah Criminal Offences Enactment (State of Sabah, 1995) for the offence of having illicit intercourse with a woman named Murni which resulted in her giving birth to an illegitimate child. To prove the case in court, the prosecutor submitted the testimony of an expert witness. The said expert witness testified that the Deoxyribonucleic Acid (DNA) test was conducted on the accused and his partner proved that the accused was the father of the illegitimate child. The accused was later given the opportunity to take an alternative DNA test to refute the prosecution's medical evidence. The accused failed to present any evidence but argued that the results of the DNA test presented by the prosecutor cannot be used as evidence to prove the case against him pursuant to s. 86(1) of the Syariah Courts Evidence Enactment (State of Sabah, 1992) which states that "Evidence in the case of adultery that carries hudud punishment is not acceptable unless witnessed by four male witnesses".

Following this, the court called upon the accused to enter his defence. The main question was whether the accused would be able to cast any reasonable doubt on the prosecution's case.

The Syarie Prosecutor had succeeded in proving the prosecution's case based on expert evidence through scientific proof, namely in the form of DNA test reports. DNA tests were conducted on 
the blood specimens of the three donors, namely Hasmawi Abdullah, Murni binti Muhammad, and Rosli bin Abdul Japar. The DNA tests were conducted by a DNA expert named Mohd Izuan bin Othman from the Department of Chemistry Malaysia, Petaling Jaya, Selangor.

Pursuant to s. 33(1), 33(2), and 33(3) of the Syariah Courts Evidence Enactment (State of Sabah, 1992), the court accepted the expert evidence as proof of adultery. The court also accepted the prosecution's argument that there was a strong indication that the accused's relationship with Murni led to illicit intercourse and the birth of an illegitimate child. The failure of the defence to submit alternative DNA test results gave rise to two possibilities, namely: (i) such test results, if submitted, would be detrimental to their case; and (ii) the results of the test is not different compared to the first test made by the prosecution.

The Case of Eddyham bin Zainuddin v. Rahimah binti Muhamad (05000-0060011-2012). This case is an unreported case that was initially heard in the Seremban Syariah High Court. It is concerned with the determination of lineage and the decision of the High Court was delivered on 15 August 2012. This case has been cited as an example to show that the Syariah Courts in Malaysia do accept the opinions of forensic experts as an admissible form of evidence to be considered when they decide on cases.

In this appeal case, the appellant was not satisfied with the decision made by the Seremban Syariah High Court Judge that the appellant's second son, Muhamad Syafiq bin Eddyham, was in fact the appellant's legal or biological son. Based on the application made by the appellant, the court directed the appellant to conduct a scientific deoxyribonucleic acid (DNA) test to obtain more accurate confirmation regarding the lineage of the child. Consequently, the DNA test was performed by the Forensic Division of the Department of Chemistry Malaysia using the blood samples of the appellant, the respondent, and also the child.

After analyzing the blood samples from the three individuals involved, the chemist, Normazlina Zainuddin, reported in writing that the appellant was not the biological father of the child. However, the trial judge rejected the chemist's written report because the expert witness had not been called to the court to testify that the child was not the appellant's biological child, as allowed by s. 33 of the Syariah Courts Evidence Enactment (Negeri Sembilan, 2003). At the same time, the appellant was found to have deliberately delayed the action of denial of the lineage. If this particular issue is viewed from an Islamic point of view, it should not be delayed. Therefore, the court decided that the written report should be rejected.

Based on the above two cases, it can be concluded that forensic evidence has been relied on by the Syariah Courts of Malaysia in cases involving the determination of a child's lineage which involves a scientific report issued by a recognized chemist.

Divorce Confirmation Case. Forensic evidence is also accepted in divorce confirmation cases such as in cases involving 
allegations of black magic influence and also in cases involving the state of a person's mental health when pronouncing divorce.

The Case of Mohd Zulhaini Uzir v. Fadzlina Mohd Fadzil [2012] 1 CLJ (SYA). This case is a divorce application case between Mohd Zulhaini Uzir and Fadzlina Mohd Fadzil. In this case, the appellant appealed against the decision made by the Judge of the Syariah Subordinate Court that the triple divorce pronounced by the appellant against his wife (respondent) on 20 August 2011 was valid under Islamic law. The appellant argued that the court erred in failing to take into account the fact that the appellant was in a state of rage and without consciousness when he pronounced the divorce.

It was further argued that the trial court should have called a forensic psychiatrist to determine the appellant's mental state at the time when he pronounced the divorce, but the trial court had failed to do so. The court should have also considered that the respondent was three months pregnant at the material time as alleged by the appellant. Based on the judgment notes, the trial judge made a statement about the appellant's conduct while testifying in court, saying that was often difficult for the appellant to answer court questions clearly, and he also misleadingly changed his answers. But the trial judge erred by not taking into account why the appellant so acted like that. It was likely that the situation occurred because the appellant had been bewitched. Based on the testimony of the respondent, the appellant had ever been treated for black magic.
By right, the trial judge should use the provisions of s. 33 of the Syariah Courts Evidence Enactment (State of Penang, 2004) to call a forensic psychiatrist in order to determine the appellant's level of sanity and not merely rely on the appellant's evidence alone. Accordingly, the court ordered the appellant and the respondent to be called back immediately so that the case could be retried in relation to the issues that had been stated.

The Case of Zakaria@Supar bin Aliv. Haznah@Maznah binti Embong [2012] 2 ShLR 12. This case is a divorce case with a triple talaq pronouncement. On October 27, 2006, at about $8 \mathrm{pm}$, the appellant pronounced divorce on the respondent with the words, "I divorce you with three talaq". Before the divorce was pronounced, there was a fight involving the appellant, the respondent, and their children. The appellant became angry when the respondent talked back to him. The appellant also almost hit his daughter but was then stopped by his son who pushed the appellant to the bed. Then, the appellant quickly got up and went on to say to the respondent, "Ok, I divorce you with three talaq". In his testimony in court, the appellant had explained that while he was pronouncing the divorce on the respondent, he had lost self-control and was in a state of over-anger and depression.

Based on the appellant's statement, the judge of the Marang District Syariah Subordinate Court decided that there had been triple talaq that took place outside the court and without the court's permission. 
The court in making the decision referred to the medical report made by Dr. Wan Munazri bin Wan Mustafa, a psychiatrist, Department of Psychiatry and Mental Health, Sultanah Nur Zahirah Hospital, Kuala Terengganu. The medical report stated that the applicant had received psychiatric treatment since August 1992 until the time when the case took place. The appellant had been diagnosed with organic personality change with depressive illness. The appellant often got into an epileptic state due to having been involved in accidents, and he was also often irritable, overly sensitive, impulsive, anxious, and had low self-control especially when he was in about of depression.

The Syariah High Court was of the opinion that the Marang District Syariah Subordinate Court had not carefully evaluated the appellant's state of mind before making a decision and had failed to call Dr. Wan Munazri bin Wan Mustafa, a psychiatrist in charge of making a medical report on the appellant to come to court and answer several questions. It was found that the failure of the Marang District Syariah Subordinate Court to call the relevant psychiatrist to give evidence had left these questions unanswered.

Based on the above two cases relating to confirmation of the pronouncement of divorce, it is clear that forensic evidence is accepted by the Syariah Court to determine the condition of the husband when pronouncing the talaq, to evaluate whether he may have been under the influence of black magic or was an unstable mental state. Although there are cases that do not refer to expert witnesses before judgment is made, the arguments given indicate that expert evidence is often needed to explain the findings in the scientific reports to the court.

Thus, it can be concluded that forensic evidence has been accepted by judges in the Malaysian Syariah Courts to resolve certain cases, as demonstrated in the above three cases. Case analysis shows that forensic evidence can be accepted in Islamic evidence law as a form of evidence to establish facts.

\section{CONCLUSIONS}

From the above discussion, it can be concluded that forensic evidence can be accepted as one form of proof for certain cases in order to help judges make fair and informed decisions. From the excerpts of the Quran cited and the Prophet's traditions, it can be said that forensic evidence has existed and been practised in the history of Islamic law. In addition, it can be said that forensic evidence can be used as qarinah which can strengthen other forms of evidence in proving criminal and civil cases.

In the present Islamic judicial legal system, evidence given by forensic experts is equivalent to the opinion of experts, also known in Arabic as ra'y al-khabir. Such form of evidence through the testimony of a qualified person in relation to a particular field is now considered as acceptable. The opinion given by such an expert is based on his or her specific high-level knowledge. In this case, the judge will place reliance on the opinion of experts to assist him in deciding a case fairly. Therefore, it can 
be concluded that forensic evidence for the purpose of establishing proof is not something unfamiliar and foreign in the Islamic judicial system.

\section{ACKNOWLEDGEMENTS}

This work was funded by The Ministry of Higher Education Malaysia - Fundamental Research Grant Scheme (FRGS) FRGS/1/2017/SS06/UKM/03/2.

\section{REFERENCES}

al-Mawdudi, A. A. (1978). Towards understanding Islam. Idara Tarjuman U1-Qur'an.

al-Qurubi, A. 'A. A. M. A. a.-A. (1950), al-Jami ' li ahkam al-Qur'an [Collection of laws of the Quran] (Vol. 20). Maba'ah Dar al-Kutub alMisriyyah.

al-Sarakhsi, S. a.-D. (1986). al-Mabsut [The extensive] (Vol. 30). Dar al-Ma'rifah.

al-Zuhayli, M. (1998). al-Ithbat fi al-sharia'h alIslamiyyah [The conviction in Islamic law]. Dar al-Makatib.

Bahnasi, A. F. (1962). Nazariyyat al-ithbat [The theory of prosecution]. al-Sharikah al-'Arabiyyah li alTiba'ah.

Eddyham bin Zainuddin v. Rahimah binti Muhamad (2012) 05000-006-0011-2012.

Glugston, M. J. (1998). The new penguin dictionary of science. The Penguin Group.

Hoyland, R. G. (2005). Physiognomy in Islam. Jerusalem Studies in Arabic and Islam, 30, 361-402.

Ibn Farhun, B. A. al-W. I. (1884). Tabsirat al-hukkam fi usul al-aqdiyyah wa manahij al-ahkam [Judges notes of the fundamentals in judgments and legal rulings approaches]. al-Matba'ah al-Bahiyyah.

Ibn Qayyim, S. A. 'A. (n.d). al-uruq al-hukmiyyah $f i$ al-siyasah al-shar iyyah [Judgmental methods on legitimate policy]. In M. H. al-Faqi (Ed.). Dar al-Kutub al-'Ilmiyyah.

Anas, M, A. 'A. (1989). Muwatta' Imam Malik [Muwatta' of Imam Malik] (M. Rahimuddin, Trans.). Kitab Bhavan.

Mohd Zulhaini Uzir v. Fadzlina Mohd Fadzil, 1 CLJ (SYA) (2012).

Pass, A. E., \& Allan, D. (2009). Forensic! Hamilton Printing Company.

Qadri, A. A. (1973). Islamic jurisprudence in the modern world. Sh. Muhammad Ashraf.

Sabah State Syarie Prosecutor v. Rosli Abdul Japar, 1 CLJ SYA 496 (2007).

Shabana, A. (2012). Paternity between law and biology: The reconstruction of the Islamic law of paternity in the wake of DNA testing. Zygon, 47(1), 214-239. https://onlinelibrary.wiley.com/ doi/abs/10.1111/j.1467-9744.2011.01246.x

Syariah Courts Evidence Enactment (State of Sabah) 1992 s. 33(1), 33(2), 33(3), s. 86(1) (Malaysia).

Syariah Courts Evidence Enactment (Negeri Sembilan) 2003 s. 33 (Malaysia).

Syariah Courts Evidence Enactment (State of Penang) 2004 s. 33 (Malaysia).

Syariah Criminal Offences Enactment 1995 (State of Sabah) s. 80(1) (Malaysia).

Zakaria@Suparbin Aliv.Haznah@Maznahbinti Embong, 2 ShLR 12 (2012).

Zaydan, A. K. (1984). Nizam al-qada'fi al-shariah alIslamiyyah [The judiciary system on the Islamic law]. Matba'ah al-Ani. 